\title{
MINT
}

\section{Colin Hamilton}

Crushed leaves lace her boot soles, their fragrance mingling with the sweat of well-worked gloves.

Another day is worn to dusk in the same dry acres.

Another day in Oregon hills, under a sky is so low each thing is pressed into ever thicker scents.

Making everything slow, and herself always the same.

Repeating the simple incantation-dirt, sun, water and seed- until they have become a single word.

And the word grows, sweet and green, at her feet. 